\title{
Tentative correlation of Cambrian Series 2 between South China and other continents
}

\author{
JINLIANG YUAN, XUEJIAN ZHU, JIHPAI LIN \& MAOYAN ZHU
}

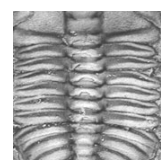

\begin{abstract}
The apparent absence, in Cambrian Series 2, of widespread and rapidly evolving organisms comparable to the later agnostids, graptolites, conodonts, ammonites, or planktonic foraminifers, has prevented a consistent intercontinental biostratigraphy. Occasional genera, and (rarely) species, of trilobites, archaeocyathans and other groups may be found in more than one region. Nevertheless, based on the complete trilobite and archaeocyathan successions in the shallow water Yangtze Platform and in deeper water Jiangnan Slope environment, correlation of Cambrian Series 2 between South China and other continents is discussed in detail. The oldest trilobite Parabadiella and Tsunyidiscus in South China can be correlated with the oldest trilobite Abadiella in Australia, Profallotapis in Siberia and Eofallotaspis in Morocco. - Key words: Cambrian Series 2, correlation, South China, other continents.
\end{abstract}

YUAN, J.L., ZHU, X.J., LIN, J.P. \& ZHU, M.Y. 2011. Tentative correlation of Cambrian Series 2 between South China and other continents. Bulletin of Geosciences 86(3), 397-404 (2 tables). Czech Geological Survey. Prague, ISSN 1214-1119. Manuscript received December 17, 2010; accepted in revised form July 1, 2011; published online September 22, 2011; issued September 30, 2011.

Jinliang Yuan, Nanjing Institute of Geology and Palaeontology, Chinese Academy of Sciences, Nanjing 210008, China; yuanjl403@sohu.com •Xuejian Zhu, Jihpai Lin \& Maoyan Zhu, State Key Laboratory of Palaeontology and Stratigraphy, Nanjing Institute of Geology and Palaeontology, Chinese Academy of Sciences, Nanjing, 210008, China

International correlation of Cambrian Series 2 has been a major problem since the concept of four series within the Cambrian was established (Peng \& Babcock 2005).

Three principal problems hamper effective inter-continental correlation of Cambrian Series 2 rocks and faunas. First, the high endemicity of Cambrian trilobite faunas is controlled by lithofacies, different environments have been sampled in different regions: Siberian, Australian, and Antarctic Cambrian Series 2 faunas are predominatly from carbonate regimes; Morrocan, Spanish, Chinese, Avalonian, and Baltic faunas are from predominatly siliciclastic regimes; and Laurentian faunas are mostly from inner shelf siliciclastics and shelf carbonates. Second, there were strong biofacies controls on the details of Cambrian associations within each of the major paleogeographic regions, including 3 main faunal Realms: the Oriental Realm, the Occidental Realm and the Medial Realm (Lu et al. 1974a), but evaluation of these controls for much of the world remains uncertain. Finally, there was a well-differentiated biogeography through much of Cambrian Series 2 time, because even comparable lithofacies on different Cambrian continents do not always contain comparable faunal elements; and palaeogeographies that reflect the macrofacies are not yet available for all areas ( $\mathrm{Lu}$ et al. 1974a, Palmer 1998). In addition, substantial hiatuses in the stratigraphic record, and inconsistencies in taxonomic nomenclature lead to paucity of biostratigraphically useful data in key regions (Palmer 1998, Geyer 2001).

Widespread and rapidly evolving organisms, comparable to the later agnostids, graptolites, conodonts, ammonites, or planktonic foraminifers, are generally lacking in Cambrian Series 2 making it more difficult to achieve a consistent intercontinental biostratigraphy. Occasional genera, and (rarely) species of trilobites, archaeocyathans and other classes may be found in more than one region, but often correlations depend on faunal similarites at the family level.

Nevertheless, some trilobite assemblages are considered to have potential for correlation. The first level is the base of the Cambrian Series 2, defined by the FAD of trilobites. There are different opinions about correlation of the oldest trilobite-bearing beds of China with other continents, especially with the Siberian Platform (S.G. Zhang 1982; Zhang et al. 1980; Zhang 1987; Repina 1986; Landing 1994; Zhuravlev 1995; Shergold 1997; Peng et al. 2004, 2006; Babcock et al. 2007; Paterson \& Brock 2007) (Table 1).

The Fallotaspidoidea in the early Atdabanian in Siberia, the early Issendalenian in Morocco, the early Waucoban in North America, was considered to include the earliest trilobites and ancestral to other trilobites (Shergold 1997, Jell 2003). 
Table 1. Comparative correlations of the oldest trilobite-bearing beds of China into Siberian Lower Cambrian trilobite biostratigraphy.

\begin{tabular}{|c|c|c|c|c|c|c|c|c|}
\hline Stage & Trilobite zonation & Repina 1986 & $\begin{array}{l}\text { S.G. Zhang (1982), } \\
\text { Zhang (1987) }\end{array}$ & $\begin{array}{l}\text { Landing } \\
\text { (1994) }\end{array}$ & $\begin{array}{l}\text { Zhuravlev (1995), } \\
\text { Paterson \& Brock } \\
\text { (2007) }\end{array}$ & $\begin{array}{l}\text { Shergold } \\
\text { (1997) }\end{array}$ & $\begin{array}{l}\text { Peng et al. } \\
\text { (2006) }\end{array}$ & $\begin{array}{l}\text { Zhang (2003), } \\
\text { this paper }\end{array}$ \\
\hline \multirow[t]{2}{*}{ Botomian } & & & & XXXXX & & & & \\
\hline & Judomia-Uktaspis Zone & & & & XXXXX & & & \\
\hline \multirow{3}{*}{ Atdabanian } & Delgadella anabara Zone & XXXXX & & & & XXXXX & & \\
\hline & Fallotapis Zone & & & & & & $\mathrm{XXXXX}$ & \\
\hline & Profallotaspis Zone & & & & & & & XXXXX \\
\hline Tommotian & & & XXXXX & & & & & \\
\hline
\end{tabular}

XXXXX The oldest trilobite-bearing beds of China

However, Lemdadella Sdzuy, 1978 is one of the oldest Cambrian trilobites so far known from the Lemdad area of Morocco and southern Spain (Liñán \& Sdzuy 1978, Palmer \& Rowell 1995). This genus was found in Spain in lower part of the Fallotaspis Zone, and found in Antarctica associated with Yunnanocephalus of the Eoredlichia-Yunnanocephalus Zone of later Chiungchussuan in SW China (Palmer \& Rowell 1995), Fallotaspis Zone is the same age of Eoredlichia-Yunnanocephalus, and younger than Parabadiella Zone in SW-China. Therefore the Parabadiella Zone may be time-equivalent to Eofallotaspis Zone in Morocco and Profallotaspis jakutensis Zone in Siberia.

The second level is Hupeidiscus fengdongensisEstaingia (Zhuxiella) fangxianensis Zone from the middle-upper part of the Jiumenchong Formation in southeastern Guizhou or middle-upper part of the Shuijingtuo Formation in Hubei of early Tsanglangpuan (=Canglangpuan) in SW China. In the early Tsanglangpuan there exists a Liangshuijing Archaeocyathid Assemblage including rich Cambrocyathellus, Aldanocyathus, Rotundocyathus, Sibirecyathus, Taylorcyathus, Coscinocyathus, Chengkoucyathus, Protopharetra, Dictyocyathus and others (Zhang 1982, pp. 521, 522), of which Cambrocyathellus, Dictyocyathus and Coscinocyathus were flourishing during the middle-later Tommotian in Siberian Platform. Besides, Fomitchella Missarzhevsky, 1969 (F. yankonensis Yuan \& Zhang, 1983) has been reported from the early Tsanglangpuan of northern Guizhou and in Siberia they occur mainly in the Tommotian and early Atdabanian (Missarzhevsky 1974, Varlamov et al. 2008). Delgadella anabara (Lazarenko, 1962) occurs in the late Atdabanian on the Siberian Platform (Varlamov et al. 2008), and Delgadella may derive from Hebediscus Whitehouse, 1939 (Jell 1975, Zhang et al. 1980), while Hebediscus Whitehouse, 1939 may have evolved from the oldest eodiscoid Hupeidiscus or Tsunyidiscus, which range biostratigraphically from lower part of Eoredlichia-Yunnanocephalus Zone (late Chiungchussuan) to Drepanuroides Zone (early Tsanglangpuan) (Lin 2008; Yang et al. 2003, 2005). Therefore, Delgadella anabara Zone should be much younger than Hupeidiscus orientalis Zone or
Tsunyidiscus niutitangensis Zone in South China Slope area. The first true Hebediscidae, Delgadella Walcott, 1912, appears in the Delgadella anabara-Nevadella Zone in the later Atdabanian. However, the Hebediscidae is not as old as the Tsunyidiscidae including Hupeidiscus, Shizhudiscus, Tsunyidiscus, because the genera assigned to Hebediscidae, Delgadella, Hebediscus, and Hebediscina have wider glabella and pygidial axis, narrower fixigenae between palpebral lobes. Therefore the late Atdabanian in Siberia can be correlated with the early Tsanglangpuan in Southwest China.

The third level is Ichangia-Neocobboldia Zone. Neocobboldia dentata (Lermontova, 1940) from the Bergeroniellus micmacciformis-Erbiella Zone at the base of the Botomian is similar to N. minor Zhou in Zhou \& Lin, 1978 from the uppermost Shuijingtuo Formation (Zhou \& Lin 1978, p. 145, pl. 20, figs 1-4; Sun 1984, pl. 119, figs 4,5$)$, and they may be synonymous. Therefore Ichangia-Neocobboldia Zone of middle Tsanglangpuan for South China and Bergeroniellus micmacciformisErbiella Zone on the Siberian Platform may be correlated. Besides, abundance of syringocnemidids, korovinellids and claruscoscinids among the archaeocyathans allows correlation of the upper Botoman Bergeroniellus ornata Zone in Siberia with the Syringocyathus aspectabilis Zone of the Altay-Sayan Foldbelt, the Yingzuiyan Archaeocyathid Assemblage of the Yangtze Platform, SW China, the Jebileticoscinus-Paranacyathus-Porocyathus Assemblage of Morocco, and the Pycnoidocoscinus serratus-Tabulaconus kordeae Zone of Laurentia (Zhuravlev 1995). In northern Gansu and northwestern Xinjiang, northwestern China and the Siberian Platform the trilobites Serrodiscus, Calodiscus and Edelsteinaspis have been recorded (T.R. Zhang 1987, Xiang \& Zhang 1985, Zhuravlev 1995) allowing this level (middle Tsanglangpuan) to be correlated with the lower-middle Botomian.

The fourth level is Protolenella conica-Chengkouia Zone or Paokannia-Szechuanolenus Zone. From Ichangia-Neocobboldia Zone to Protolenella conica-Chengkouia Zone or from Ushbaspis Zone to Paokannia-Szechuanolenus Zone there is a distinctly regressive 
event in Southwest China. This level coincides with the global Hawke Bay regressive event. The base of Cambrian Stage 4 would be defined by the FAD of Redlichia or Olenellus (Peng et al. 2004, 2006; Babcock et al. 2007). The oldest species of Redlichia so far known from SW-China is Redlichia $(R$.) premigena Lin \& Yin in Zhang et al. 1980 (Zhang et al. 1980, p. 125, pl. 19, figs 3-5) within the Paokannia-Szechuanolenus Zone and Ushbaspis Zone of the middle Tsanglangpuan (= Canglangpuan), which is intermediate between the Palaeolenus lantenoisi Zone (late Tsanglangpuan) and the Drepanuroides Zone (early Tsanglangpuan) or between Protolenella conioca-Chengkouia Zone and Arthricocephalus jiangkouensis Zone. In this interval trilobite faunal turnover is obvious. The older redlichioids and eodiscoids including Pararedlichiinae, Anadoxididae, Tsunyidiscidae, Hebediscidae disappear; protolenids and yinitids are dominated (Yuan et al. 2002). Sharp faunal changes can be observed in those areas between the earlist Toyonian and middle Toyonian in Siberia, and at the bottom of the Olenellus Zone in Laurentia, at the base of the Hupeiolenus Zone in Morocco, approximately at the base of the Hamatolenus ibericus Zone in Spain, which should be allowed to correlate this level in SW China with those levels above mentioned in other continents (Palmer \& Repina 1997, Yuan \& Zhao 1999).

The fifth level is Arthricocephalus chauveaui Zone. FAD of Arthricocephalus chauveaui was defined for the base of the Duyunian Stage (Peng \& Babcock 2001). Later, Geyer suggested that FAD of Arthricocephalus chauveaui is marked the base of traditional Middle Cambrian (Geyer 2005). In Southwest China Arthricocephalus chauveaui Zone is time-equivalent to the Palaeolenus deprati Zone and $P$. fengyangensis Zone of later Tsanglangpuan (= Canglangpuan). The trilobite Schistocephalus Lermontova in Tchernysheva et al., 1956 is a junior homonym of Schistocephalus Creplin, 1829 (Özdikmen, 2009) and a junior synonym of Palaeolenus Mansuy, 1912 (Rushton \& Powell, 1998), therefore Schistocephalus antiquus Tchernysheva in Tchernysheva et al., 1956 should be replaced by Palaeolenus antiquus (Tchernysheva in Tchernysheva et al., 1956). Morphologically this species is quite similar to Palaeolenus fengyangensis Chu, 1959, with which it may be synonymous. The Mass extinction of archaecyaths took place during this interval, which coincides with Botomian-Toyonian crisis between the Anabaraspis splendens Zone and Lermontovia grandis Zone of Toyonian in Siberian Platform (Brasier et al. 1994). Thus the early Amgan Palaeolenus antiquus Zone in Siberia can be correlated with Palaeolenus fengyangensis Zone or upper part of the Arthricocephalus chauveaui Zone in South China.

The sixth level is Dinesus panxinicus-Olenoides constrictus Zone of the lower-middle part of the
"Tsinghsutung Formation" (middle Duyunian or early Lungwangmiaoan) in SE Guizhou, SW China. With exception of Dinesus panxinicus, Olenoides constrictus, many trilobite genera and species occur in this interval, such as, Redlichia, Kootenia, ?Kooteniella, Panxinella angustilimbata Lin in Lu et al., 1974a, P. xiunaoensis Qian \& Lin in Zhang et al., 1980, Changaspis plana (Tomashpolskaya, 1960), Lancastria, Parachangaspis including Kunshanaspis, ptychopariids and the vestiges of Arthricocephalus. Morphologically, Dinesus panxinicus Zhu \& Yuan in Zhu et al., 2009 (pl. 1, figs 5-12) is quite similar to Dinesus granulosus (Lermontova, 1940) and Dinesus sibiricus (Schmidt, 1886), which range from Lermontovia grandis Zone through the Anabaraspis splendens Zone, Palaeolenus antiquus Zone, and Ovatoryctocara Zone to Kounamkites Zone (Egorova et al. 1976, Repina \& Romenenko 1978); Olenoides constrictus (Chien, 1961) is widely distributed not only in SW China, but also in North Greenland, where Olenoides sp. A. from the lower part of the Henson Gletscher Formation can be assigned to Olenoides constrictus (Chien, 1961) (Blaker \& Peel 1997, p. 86, figs 42.2, 8, 9; 49.10); Arthricocephalus occurs both in the early-middle Duyunian (from Arthricocephalus jiangkouensis Zone to the lower part of Ovatoryctocara cf. granulata-Bathynotus holopygus Zone) of SW China, the upper Olenellus Zone of North Greenland and the Jigaimara Formation (earlist Templetonian), Arafura Basin, Northern Territory, Australia (Yuan et al. 2009, Blaker \& Peel 1997, Laurie 2006). Therefore, Dinesus panxinicus-Olenoides constrictus Zone can be correlated with upper Palaeolenus antiquus Zone and lower Ovatoryctocara Zone in Siberia, and the upper Olenellus Zone in Laurentia.

The seventh level is Ovatoryctocara cf. granulataBathynotus holopygus Zone. Ovatoryctocara granulata has been found not only in the early Amgan Ovatoryctocara Zone in Siberia, but also in the upper Olenellus Zone in North Greenland. Bathynotus is widespread in South China, NW China, western and eastern Laurentia, Siberia and Australia (Peng et al. 2009, Webster 2009).

The eighth level is the Oryctocephalus indicus Zone. The FAD of Oryctocephalus indicus is defined the base of Cambrian Stage 5 and Cambrian Series 3. This species is widespread in South China, Himalaya (India), Korea, North America and Siberia (Yuan et al. 1997, 2002; Zhao et al. 2006, 2007); this level also corresponds to the second mass extinction of trilobites (Yuan et al. 2002). The base of Oryctocephalus indicus Zone corresponds to the base of the Kounamkites Zone on the Siberian Platform, the base of Oryctocephalus indicus Zone or Poliella denticulata Zone or Oryctocephalus indicus Zone in Laurentia (Sundberg \& McCollum 1997, 2003a, b).

The South Australian Abadiella huoi Zone correlates with the Parabadiella Zone based on the occurrence of 
Table 2. Correlation of Cambrian Series 2 between South China and other continents.

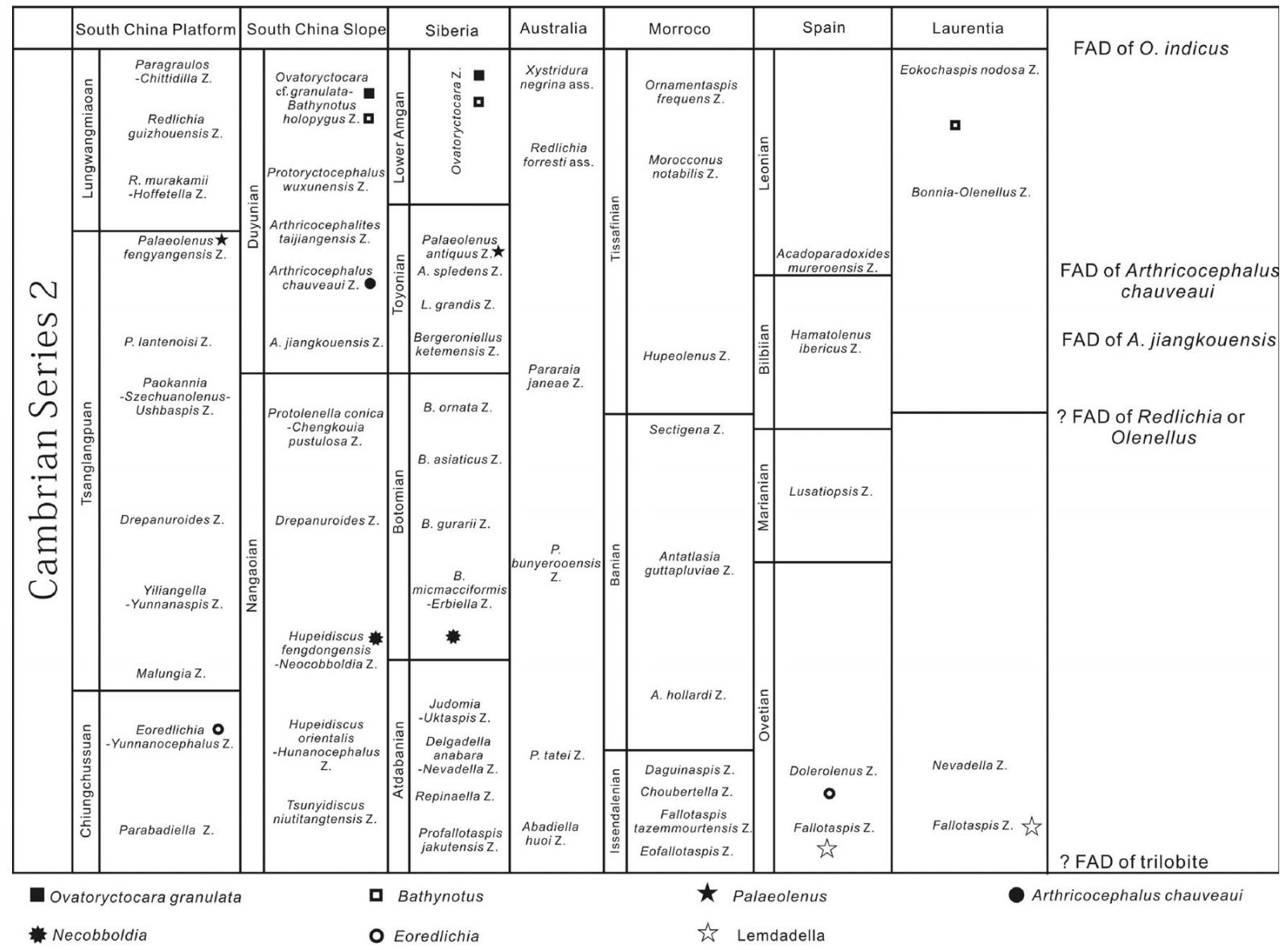

P. huoi in the both regions (Zhang 1985, 2003; Jell in Bengtson et al. 1990; Steiner et al. 2001; Zhang et al. 2001; Paterson \& Brock 2007). The Pararaia tateri Zone from the Parara Limestone contains Wutingaspis jelli Zhang in Zhang et al., 2001 and can be correlated with Eoredlichia-Wutingaspis Zone (Zhang et al. 2001). However, Wutingaspis ranges from upper part of Parabadiella Zone to Eoredlichia Zone (Luo et al. 1994, 2008), we establish here Eoredlichia-Yunnanocephalus assembalge Zone instead of Eoredlichia-Wutingaspis assemblage Zone. Pararaia bunyerooensis Zone and Pararaia janeae Zone contain Hebediscina yuqingensis (Zhang in Yin \& Lee, 1978), which occurs in the middle-upper part of the Jiumengchong Formation in South China, which is time-equivalent to early-middle Tsanglangpuan in SW China. The co-occurrence of Redlichia endoi both in the Micmaccaspis assemblage in Australia and Palaeolenus lantenoisi Zone in SW China allows correlation of middle-late Tsanglangpuan with Micmaccopsis assemblage from the upper Wilkawillina Limestone (Zhang et al. 1980, Zhou \& Yuan 1980, Paterson \& Brock 2007); trilobites higher in the succession in Australia are found in only a few horizons, for example, known from the Billy Creek
Formation, the Wirrealpa Limestone, and from the upper part of the Moodlatana Formation (Paterson \& Edgecombe 2006; Jell in Bengtson et al. 1990), of which Redlichia guizhouensis and Bathynotus holopygus occur both in SW China and South Australia (Jago et al. 2006, Paterson \& Brock 2007), and are equivalent to late Duyunian or Lungwangmiaoan. It is worth noting that the Arthricocephalus sp. nov. has been recorded from the Jigaimara Formation, Arafura Basin, Northern Territory, and associated with Pagetia aff. edura Jeel, Xystridura altera Öpik, ptychoparioid sp. 1 and Itagnostus sp. of the early Templetonian in age (Laurie 2006). Arthricocephalus ranges from the Balang Formation, via the Wuxun Formation ("Tsinghsutung Formation") to the lowest part of the Kaili Formation (Duyunian or late Tsanglangpuan to Lungwangmiaoan) in SW China (Yuan et al. 2009). Besides, the Xystridura-bearing strata at Yaxian, Hainan Province was considered as a traditional lowermost Middle Cambrian (Lin \& Jago 1993), however, the associated Pagetia luoyacunensis Lin \& Jago was regarded as a possible synonym of Kiskinella cristata Romanenko \& Romanenko, 1962, which occurs in Ovatoryctocara granulata Zone of Siberia, southeastern Newfoundland (Fletcher 2003, Geyer 
2005), thus the Xystridura-bearing strata may probably belong to latest Duyunian. Dinesus was formerly regarded as a typical traditional early Middle Cambrian trilobite taxon (Jell \& Adrain 2003), however, Dinesus panxinicus Zhu \& Yuan in Zhu et al., 2009, D. burus (Qiu, 1980), D. ocellatus (Qiu, 1980), D. spinellosus (Zhou in Zhou et al., 1982) except D. kirghizensis Lermontova, 1951, occur in traditional Lower Cambrian in China (late Duyunian or late Lungwangmiaoan). Therefore the early Templetonian may be partly correlated with late Duyunian or late Lungwangmiaoan.

Lower Cambrian trilobite successions of Morocco have been well documented (Hupé 1953; Sdzuy 1978; Geyer 1990, 1996; Geyer \& Landing 1995). The oldest trilobite Lemdadella Sdzuy, 1978 occurs in the Fallotaspis tazemmourtensis Zone. It seems reasonable the Fallotaspis tazemmourtensis Zone together with Calcaire Superieur should be equivalent to the Eoredlichia-Wutingaspis Zone in SW China (Zhang 1998); while Choubertella Zone and Daguinaspis Zone of later Issendalenian may be correlated with uppermost Eoredlichia-Yunnanocephalus Zone (latest Chiungchussuan) or Malungia Zone of earliest Tsanglangpuan in SW China. Antatlasia hollardi Zone, Antatlasia gutta-pluviae Zone and Sectigena Zone of the Banian may fall within the Yiliangella-Yunnanaspis Zone, Drepanuroides Zone and Ushbaspis Zone (early-middle Tsanglangpuan) in SW China. The base of the STH "Band" has been proposed as a GSSP for the base of a terminal "Lower Cambrian" stage, because associations with such trilobites as Serrodiscus bellimarginatus, Triangulaspis annio, T. schucherti, and Hebediscus attleborensis are distributed in the traditional Lower Cambrian (Cambrian Series 2) of western Avalonia, eastern Avalonia, Taconic Laurentia, West Gondwana, the Altay-Sayan fold Belt, the Siberian Platform, the Russian Far East region and with restrictions even in Laurentian Greenland and South Australia (Geyer, 2005). The Hupeolenus Zone of early Tissafinian can be correlated with Paokannia-Szechuanolenus Zone (middle Tsanglangpuan), because Szechuanolenus Chang \& Chu in Yin \& Lee, 1978, with S. nanjingensis Chang \& Chu in Yin \& Lee, 1978 as the type species (Yin \& Lee 1978, p. 424, pl. 152, figs 20, 21; Zhang et al. 1980, p. 236, pl. 75, figs 1-4), is quite similar to Hupeolenus Geyer, 1990, with Protolenus (Hupeolenus) hupei Geyer, 1990 as the type species (Geyer 1990, pp. 184-186, pl. 36, fig. 5; pl. 46, figs 1-18) in general outline of cranidium and glabella, the pattern of lateral glabellar furrows, the width of fixigenae between palpebral lobes and the length and position of palpebral lobe. Therefore Hupeolenus may be a junior synonym of Szechuanolenus. The trilobite genus Cephalopyge Geyer, 1988 is a junior homonym of Cephalopyge Hanel, 1905 (Özdikmen, 2009), and the replacement name is Morocconus Özdikmen, 2009. In the Morocconus notabilis Zone Palaeolenus ornatus (Geyer,
1998) and Shergoldiella vincenti Geyer, 2006 have been recorded. Therefore Morocconus notabilis Zone may be a time equivalent to Palaeolenus Zone (latest Tsanglangpuan) and Dinesus panxinicus-Olenoides constrictus Zone (Lungwangmiaoan or later Duyunian), because a few illustrated specimens that were prevously assigned to Arthricocephalus chauveaui Bergeron, 1899 from the Dachenling Formation of Dongzhi, southern Anhui should be reinterpreted as Shergoldiella cf. S. sequei (Liñán \& Gozalo, 1999) (Zhu et al. 2005, Yuan et al. 2009).

Correlation of Cambrian Series 2 between South China and other continents is shown in Table 2.

\section{Acknowledgments}

This study is supported by the National Natural Science Foundation of China (40930211; 40762001) and the Chinese Academy of Sciences Project-Oriented Hundred Talents Programme (KZCX2-YW-BR-23) to Lin. Many thanks are given to Peter Jell (Brisbane), Oldřich Fatka (Praha), and an anonymous reviewer who kindly responsibly reviewed the submitted manuscript and provided very useful critical remarks.

\section{References}

BABCOCK, L.E., Robison, R.A., REES, M.N., PENG, S.C. \& SALTZMAN, M.R. 2007. The global boundary Stratotype Section and Point (GSSP) of the Drumian Stage (Cambrian) in the Drum Mountains, Utah, USA. Episodes 30(2), 85-95.

BlAKER, M.R. \& PEEL, J.S. 1997. Lower Cambrian trilobites from North Greenland. Meddelelser om Grønland, Geoscience $35,1-145$.

Bengtson, S., Conway Morris, S., CoOper, B.J., Jell, P.A. \& RUNNEGAR, B.N. 1990. Early Cambrian fossils from South Australia. Memoris of the Association of Australasian Palaeontologists 9, 1-364.

Brasier, M.D., RoZANOV, A.Y., ZHURAVlev, A.Y., CoRFIELD, R.M. \& DERRY, L.A. 1994. A Carbon isotope reference scale for the Lower Cambrian succession in Siberia: report of IGCP Project 303. Geological Magazine 131(6), 767-783. DOI 10.1017/S0016756800012851

CHIEN, Y.Y. 1961. Cambrian trilobites from Sandu and Duyun, southern Kweichou. Acta Palaeontologica Sinica 9(2), 91-129. [in Chinese with English summary]

Egorova, L.I., Shabanov, Y.Y., ROZANOV, A.Y., SAVITSKY, V.E., TCHERNYSHEVA, N.E. \& SHISHKIN, B.B. 1976. The Elanka and Kuonamka facies stratotype of the lower boundary of the Siberian Middle Cambrian. Sibirskiy nauchno-issledovatelskiy institut geologii, geofiziki i mineralnogo syr'ya (SNIIGGIMS), Trudy 211, 1-167. [in Russian]

FLETCHER, T.P. 2003. Ovatoryctocara granulata: the key to a global Cambrian stage boundary and the correlation of the olenellid, redlichiid and paradoxidid realms. Special Papers in Palaeontology 70, 73-102. 
GEYER, G. 1990. Die marokkanischen Ellipsocephalidae (Trilobita: Redlichiida). Beringeria 3, 1-363.

GEYER, G. 1996. The Moroccan fallotaspid trilobites revisited. Beringeria 18, 89-199.

GeYeR, G. 2001. Correlation in the Cambrian: Puzzling facts or wrong concepts? Palaeoworld 13, 87-98.

GEYER, G. 2005. The base of a revised Middle Cambrian: are suitable concepts for a series boundary in reach? Geosciences Journal 9(2), 81-99. DOI 10.1007/BF02910571

GEYER, G. 2006. First African oryctocephalid trilobites from the Lower-Middle Cambrian boundary interval. Palaeoworld 15, 348-359. DOI 10.1016/j.palwor.2006.10.004

GEYER, G. \& LANDING, E. 1995. The Cambrian of the Moroccan Atlas region, 7-46. In GEYER, G. \& LANDING, E. (eds) Morocco '95. The Lower-Middle Cambrian standard of western Gondwana. Introdution, Field Guide, Abstracts, and Proceedings of the First Conference of the Lower Cambrian Stage Subdivision Working Group and I.G.C.P. Project 366 Ecological Aspects of the Cambrian Radiation. Beringeria, Special Issue 2.

HuPÉ, P. 1953. Contribution à l'étude du Cambrien inférieur et du Précambrien III de l'Anti-Atlas Marocain. Notes et Mémories du Service géologique de Maroc 103, 1-402.

JAGO, J.B., ZANG, W.L., SUN, X.W., BROCK, G.A., PATERSON, J.R. \& Skovsted, C.B. 2006. A review of the Cambrian biostratigraphy of South Australia. Palaeoworld 15, 406-423. DOI 10.1016/j.palwor.2006.10.014

JELL, P.A. 1975. Australian Middle Cambrian eodiscoids with a review of the superfamily. Paläontographica, Abteilung A 150, 1-97.

JELL, P.A. 2003. Phylogeny of Early Cambrian trilobites. Special Papers in Palaeontology 70, 45-57.

JELL, P.A. \& ADRAIN, J.M. 2003. Available generic names for trilobites. Memoirs of the Queensland Museum 48(2), 331-551.

LANDING, E. 1994. Precambrian-Cambrian boundary global stratotype ratified and a new perspective of Cambrian time. Geology 22, 179-182.

DOI 10.1130/0091-7613(1994)022<0179:PCBGSR >2.3.CO;2

LAURIE, J.R. 2006. Early Middle Cambrian trilobites from the Jigaimara Formation, Arafura Basin, Northern Territory. Memoirs of the Association of Australasian Palaeontologist 32, 103-126.

LIÑÁN, E. \& SDZUY, K. 1978. A trilobite from the Lower Cambrian of Córdoba (Spain) and its stratigraphical significance. Senckenbergiana lethaea 59, 387-399.

LIN, H.L. 2008. Early Cambrian (Chiungchussuan, Tsanglangpuan and Lungwangmiaoan). Chapter 3, 36-76. In ZHOU, Z. \& ZHEN, Y. (eds) Trilobite Record of China. 401 pp. Science Press, Beijing.

LIN, T.R. \& JAGO, J.B. 1993. Xystridura and other early Middle Cambrian trilobites from Yaxian, Hainan Province, China. Transactions of the Royal Society of South Australia 117(3), $141-152$.

LU, Y.H., Chang, W.T., ChIEN, Y.Y., CHU, C.L., LIN, H.L., ZHOU, Z.Y., QIAN, Y., ZHANG, S.G. \& WU, H.J. 1974b. Cambrian trilobites, 82-107. In NANJING INSTITUTE OF GEOLOGY AND PALAEONTOLOGY, ACADEMIA SINICA (ed.) Handbook of Stratigraphy and Palaeontology, Southwest China. 454 pp. Science Press, Beijing. [in Chinese]
LU, Y.H., ChU, C.L., ChIEN, Y.Y., LIN, H.L., ZHOU, Z.Y. \& YUAN, K.X. 1974a. Bio-environmental control hypothesis and its application to the Cambrian biostratigraphy and palaeozoogeography. Memoirs of the Nanjing Institute of Geology and Palaeontology, Academia Sinica 5, 27-116. [in Chinese]

LUO, H.L., JIANG, Z.W. \& TANG, L.D. 1994. Stratotype section for Lower Cambrian stages in China. 130 pp. Yunnan Science and Technology Press, Kunming. [in Chinese]

LuO, H.L., LI, Y., HU, S.X., FU, X.P., Hou, S.G., LIU, X.Y., Chen, L.Z., LI, F.J., PANG, J.Y. \& LIU, Q. 2008. Early Cambrian Malong Fauna and Guanshan Fauna from eastern Yunnan, China. 134 pp. Yunnan Science and Technology Press, Kunming. [in Chinese with English summary]

MisSARZHEVSKY, V.V. 1974. New data on the earliest Cambrian fossils of the Siberian Platform, 179-189. In ZHURAVLEVA, I.T. \& RoZANOV, A.Y. (eds) Lower Cambrian biostratigraphy and palaeontology of Europe and northern Asia. Nauka, Moscow. [in Russian]

ÖZDIKMEN, H. 2009. Nomenclatural changes for twenty trilobites genera. Munis Entomology \& Zoology 4(1), 155-171.

PALMER, A.R. 1998. Why is intercontinental correlation within the Early Cambrian so difficult? Revista Española de Paleontología, No. extraordinario, Homenaje al Prof. Gonzalo Vidal, 17-21.

PALMER, A.R. \& REPINA, L.N. 1997. Introduction to suborder Olenellina, 405-407. In KAESLER, R.L. (ed.) Treatise on Invertebrate Paleontology, Part O, Arthropoda 1, Trilobita, Revised. 530 pp. Geological Society of America \& University of Kansas, Boulder \& Lawrence.

PALMER, A.R. \& Rowell, A.J. 1995. Early Cambrian trilobites from the Shackleton Limestone of the Central Transantarctic Mountains. The Paleontotological Society Memoir 45, 1-28.

PATERSON, J.R. \& BROCK, G.A. 2007. Early Cambrian trilobites from Angorichina, Flinders Ranges, South Australia, with a new Assemblage from the Pararaia bunyerooensis Zone. Journal of Paleontology 81(1), 116-142.

DOI 10.1666/0022-3360(2007)81[116:ECTFAF]2.0.CO;2

PATERSON, J.R. \& EDGECOMBE, G.D. 2006. The Early Cambrian trilobite family Emuellidae Pocock, 1970: Systematic position of Australian species. Journal of Paleontology 80(3), 496-513.

DOI 10.1666/0022-3360(2006)80[496:TECTFE]2.0.CO;2

Peng, J., ZhaO, Y.L., YuAN, J.L., YAO, L. \& YANG, H. 2009. Bathynotus: A key trilobite taxon for global stratigraphic boundary correlation between Cambrian Series 2 and Cambrian Series 3. Progress in Natural Science 19, 99-105. DOI 10.1016/j.pnsc.2008.03.034

PENG, S.C. \& BABCOCK, L.E. 2001. Cambrian of the HunanGuizhou region, South China. Palaeoworld 13, 3-51.

PENG, S.C. \& BABCOCK, L.E. 2005. Newly proposed global chronostratigraphic subdivision on Cambrian System. Journal of Stratigraphy 29(1), 92-93, 96. [in Chinese with English abstract]

PENG, S.C., BABCOCK, L.E., RobISON, R.A., LiN, H.L., REES, M.N. \& SALTZMAN, M.R. 2004. Global standard Stratotypesection and Point (GSSP) of the Furongian Series and Paibian Stage (Cambrian). Lethaia 37, 365-379.

DOI 10.1080/00241160410002081 
Peng, S.C., BABCOCK, L.E., ZuO, J.X., Lin, H.L., ZhU, X.J., YANG, X.F., ROBISON, R.A., QI, Y.P., BAGNOLI, G. \& CHEN, Y.A. 2006. Proposed GSSP for the base of Cambrian Stage 7, coinciding with the first appearance of Lejopyge laevigata, Hunan, China. Palaeoworld 15, 367-383.

DOI 10.1016/j.palwor.2006.10.015

QIU, H.A. 1980. Lower Cambrian trilobites of the Mantou Formation from Xuzhou-Suxian area, northern Jiangsu and Anhui. Bulletin of the Nanjing Institute of Geology and Mineral Resources, Chinese Academy of Geological Sciences 1, 34-64. [in Chinese with English abstract]

REPINA, L.N. 1986. Global correlation of stage subdivisions of the Early Cambrian according to trilobites, 4-25. In ZHURAVLEVA, I.T. (ed.) Biostratigraphy and palaeontology of the Cambrian of northern Asia. Trudy Instituta geologii $i$ geofiziki, Sibirskoe otdelenie, Akademiya nauk SSSR 669. [in Russian]

REPINA, L.N. \& RomanenKo, E.V. 1978. Trilobites and Stratigraphy of the Lower Cambrian of Altay. Trudy Instituta geologii i geofiziki, Sibirskoe otdelenie, Akademiya nauk SSSR 382, 1-304. [in Russian]

Rushton, A.W.A. \& POWELL, J.H. 1998. A review of the stratigraphy and trilobite faunas from the Cambrian Burj Formation in Jordan. Bulletin of the Natural History Museum, Geology Series 54(2), 131-146.

SDZUY, K. 1978. The Precambrian-Cambrian boundary beds in Morocco (preliminary report). Geological Magazine 115(2), 83-94. DOI 10.1017/S0016756800041133

SHERGOLD, J.H. 1997. Explanatory notes for the Cambrian correlation chart, 303-311. In KAESLER, R.L. (ed.) Treatise on Invertebrate Paleontology, Part O, Arthropoda 1, Trilobita, Revised. $530 \mathrm{pp}$. Geological Society of America \& University of Kansas, Boulder \& Lawrence.

Steiner, M., Zhu, M.Y., Weber, B. \& GeYer, G. 2001. The Early Cambrian of eastern Yunnan: Trilobite-based biostratigraphy and related faunas. Acta Palaeontologica Sinica 40 (Supplement), 63-79. [in English with Chinese abstract]

SundBERG, F.A. \& MCCOLLUM, L.B. 1997. Oryctocephalids (Corynexochida: Trilobita) of the Lower-Middle Cambrian boundary interval, from California and Nevada. Journal of Paleontology 71(6), 1065-1090.

SunDBERG, F.A. \& MCCOLLUM, L.B. 2003a. Oryctocephalids (Corynexochida: Trilobita) of the Lower-Middle Cambrian boundary interval from California and Nevada. Journal of Paleontology 77(2), 331-359.

DOI 10.1666/0022-3360(2003)077<0331:TOTLMC >2.0.CO;2

SundBerG, F.A. \& MCCOlLuM, L.B. 2003b. Early and Mid Cambrian trilobites from the outer-shelf deposits of Nevada and California, USA. Palaeontology 46(5), 945-986. DOI $10.1111 / 1475-4983.00328$

Sun, Z.H. 1984. Trilobita, 328-422. In REGIONAL GEOLOGICAL SURVEYING TEAM OF HUBEI (ed.) Palaeontological Atlas of Hubei Province. 812 pp. Hubei Science and Technology Press, Wuhan. [in Chinese]

VArlamov, A.I., Rozanov, A.Y., Khomentovsky, V.V., Shabanov, Y.Y., Abaimova, G.P., DemidenKo, Y.E., KARLOVA, G.A., KOROVNIKOV, I.V., LUCHININA, V.A., MALAKHOVSKAYA, Y.E., PARKHAEV, P.Y., PEGEL, T.V., SKORLOTOVA, N.A., SundOKOV, V.M., SUKHOV, S.S., FEDOROV,
A.B. \& KiPRIYANOVA, L.D. 2008. The Cambrian System of the Siberian Platform. Part 1: The Aldan-Lena Region. 300 pp. Moscow \& Novosibirsk. [in Russian and English]

WEBSTER, M. 2009. Systematic revision of the Cambrian trilobite Bathynotus Hall, 1860, with documentation of new occurrences in western Laurentia and implications for intercontinental biostratigraphic correlation. Memoirs of the Association of Australian Palaeontologists 37, 369-406.

XIANG, L.W. \& ZHANG, T.R. 1985. Description of the trilobites, 64-165. In WANG, J. et al. Stratigraphy and trilobite faunas of the Cambrian in the western part of the Northern Tianshan, Xinjiang. Ministry of Geology and Minineral Resources, Geological Memoirs, Series 2, Stratigraphy and Palaeontology 4. 243 pp. Geological Publishing House, Beijing. [in Chinese with English summary]

YANG, A.H., ZHU, M.Y. \& ZHANG, J.M. 2005. Stratigraphic distribution and palaeogeographic control on the Early Cambrian eodiscoids in Yangtze Platform. Journal of Palaeogeography 7(2), 219-232. [in Chinese with English abstract]

YANG, A.H., ZHU, M.Y., ZHANG, J.M. \& LI, G.X. 2003. Early Cambrian eodiscoid trilobites of the Yangtze Platform and their stratigraphic implications. Progress in Natural Science 13(11), 861-866. DOI 10.1080/10020070312331344560

YIN, G.Z. \& LEE, S.J. 1978. Trilobita, 385-595. In Palaeontological Atlas of Southwest China, Guizhou Province 1: Cambrian-Devonian. 843 pp. Geological Publishing House, Beijing. [in Chinese]

YUAN, J.L. \& ZHAO, Y.L. 1999. Subdivision and correlation of Lower Cambrian in Southwest China, with a discussion of the age of early Cambrian series Biota. Acta Palaeontologica Sinica 38 (Supplement), 116-131. [in Chinese with English summary]

YUAN, J.L., ZHAO, Y.L., LI, Y. \& HUANG, Y.Z. 2002. Trilobite fauna of the Kaili Formation (uppermost Early Cambrianearly Middle Cambrian) from southeastern Guizhou, South China. 423 pp. Shanghai Science and Technology Press, Shanghai. [in Chinese with English summary]

YUAN, J.L., ZHAO, Y.L., PENG, J., ZHU, X.J. \& LiN, J.P. 2009. Cambrian trilobite Ovatoryctocara granulata Tchernysheva, 1962 and its biostratigraphic significance. Progress in Natural Science 19, 213-221. DOI 10.1016/j.pnsc.2008.08.002

YUAN, J.L., ZHAO, Y.L., WANG, Z.Z., ZHOU, Z. \& CHEN, X.Y. 1997. A preliminary study on Lower-Middle Cambrian boundary and trilobite fauna at Balang, Taijiang, Guizhou, South China. Acta Palaeontologica Sinica 36(4), 494-524. [in Chinese with English summary]

ZHANG, S.G. 1982. Oldest trilobite in the world and correlation of some archaeocyathid assemblages. Acta Palaeontologica Sinica 21(5), 516-525. [in Chinese with English abstract]

ZHANG, T.R. 1987. New materials of Cambrian trilobites from Bolthinur Mountain, Xinjiang. Xinjiang Geology 5(2), 44-48. [in Chinese with English abstract]

ZHANG, W.T. 1985. Current biostratigraphic scheme of the Chinese Cambrian. Palaeontologia Cathayana 2, 73-75.

ZHANG, W.T. 1987. Correlation of the Cambrian of China. Palaeontologia Cathayana 3, 267-285.

ZHANG, W.T. 1998. Cambrian correlation within the Perigondwana faunal realm. Revista Española de Paleontología, No. extraordinario, Homenaje al Prof. Gonzalo Vidal, 23-34. 
ZHANG, W.T. 2003. Cambrian biostratigraphy of China, 55-119. In ZHANG, W.T., CHEN, P.J. \& PALMER, A.R. (eds) Biostratigraphy of China. 599 pp. Science Press, Beijing.

ZHANG, W.T., BABCOCK, L.E., XIANG, L.W., SUN, W.G., LUO, H.L. \& JIANG, Z.W. 2001. Lower Cambrian stratigraphy of Chengjiang, eastern Yunnan, China with special notes on Chinese Parabadiella. Moroccan Abadiella and Australian Abadiella huoi. Acta Palaeontologica Sinica 40(3), 294-309.

ZHANG, W.T., LU, Y. H., ZHU, Z.L., QIAN, Y.Y., LIN, H.L., ZHOU, Z.Y., ZHANG, S.G. \& YUAN, J.L. 1980. Cambrian trilobite faunas of southwestern China. Palaeontologia Sinica 159, New Series 16, 1-497. [in Chinese with English summary]

ZhAO, Y.L., YUAN, J.L., PENG, S.C., BABCOCK, L.E., PENG, J., LIN, J.P., GUO, Q.J. \& WANG, Y.X. 2007. New data on the Wuliu-Zengjiayan section (Balang, South China), GSSP candidate for the base of Cambrian Series 3. Memoirs of the Association of Australasian Palaeontologist 33, 57-65.

ZhaO, Y.L., YuAn, J.L., Peng, S.C., YAng, X.L., Peng, J., LIN, J.P. \& GUO, Q.J. 2006. A restudy of Oryctocephalus indicus (Reed, 1910). Progress in Natural Science 11, 1177-1182.

ZHOU, T.M. \& LIN, T.R. 1978. Early Cambrian trilobites, 143-154. In STRATIGRAPHIC RESEARCH GROUP OF YANGTZE Gorges, Hubei Bureau of GEOlogy (ed.) Sinian to
Permian Stratigraphy and Palaeontology of the Eastern Yangtze Gorges Area. 381 pp. Geological Publishing House, Beijing. [in Chinese]

ZHOU, Z.Q., LI, J.S. \& QU, X.G. 1982. Trilobita, 215-294. In XI'AN INSTITUTE OF GEOLOGY AND MineRAL RESOURCES (ed.) Palaeontological atlas of Northwest China, ShaanxiGansu-Ningxia 1. Precambrian and Early Palaeozoic. 480 pp. Geological Publishing House, Beijing. [in Chinese]

ZHOU, Z.Y. \& YUAN, J.L. 1980. Lower Cambrian trilobite succession in southwest China. Acta Palaeontologica Sinica 19(4), 331-339. [in Chinese with English abstract]

ZHU, X.J., PENG, S.C. \& QI, D.L. 2005. Early Cambrian trilobite fauna from Dongzhi, southern Anhui. Acta Palaeontologica Sinica 44(4), 556-566. [in Chinese with English abstract]

ZHU, X.J., YUAN, J.L., BIAN, R.C., HU, Y.S. \& DU, S.X. 2009. On the Cambrian trilobites Tingyuania and Dinesus. Acta Palaeontologica Sinica 48(4), 681-687. [in Chinese with English abstract]

ZHURAVLEV, A.Y. 1995. Preliminary suggestions on the global Early Cambrian Zonation, 147-160. In GEYER, G. \& LANDING, E. (eds) Morroco '95. The Early-Middle Cambrian standard of western Gondwana. Introduction, Field Guide, Abstracts, and Proceedings of the first Conference of the Early Cambrian Stage Subdivision Working Group and I.G.C.P. Project 366 Ecological Aspects of the Cambrian Radiation. Beringeria, Special Issue 2. 